June 2002 • NREL/TP-500-31666

\title{
Wind Turbine Generator System Safety and Function Test Report for the Southwest Windpower H40 Wind Turbine
}

J. van Dam, H. Link, M. Meadors and J. Bianchi

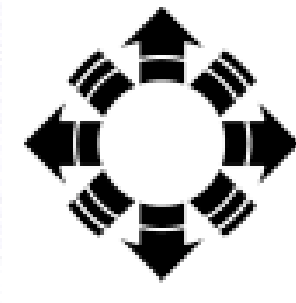

\section{NPEI}

National Renewable Energy Laboratory

1617 Cole Boulevard

Golden, Colorado 80401-3393

NREL is a U.S. Department of Energy Laboratory

Operated by Midwest Research Institute • Battelle • Bechtel

Contract No. DE-AC36-99-G010337 


\title{
Wind Turbine Generator System Safety and Function Test Report for the Southwest Windpower H40 Wind Turbine
}

\author{
J. van Dam, H. Link, M. Meadors and J. Bianchi
}

Prepared under Task No. WER2 3215

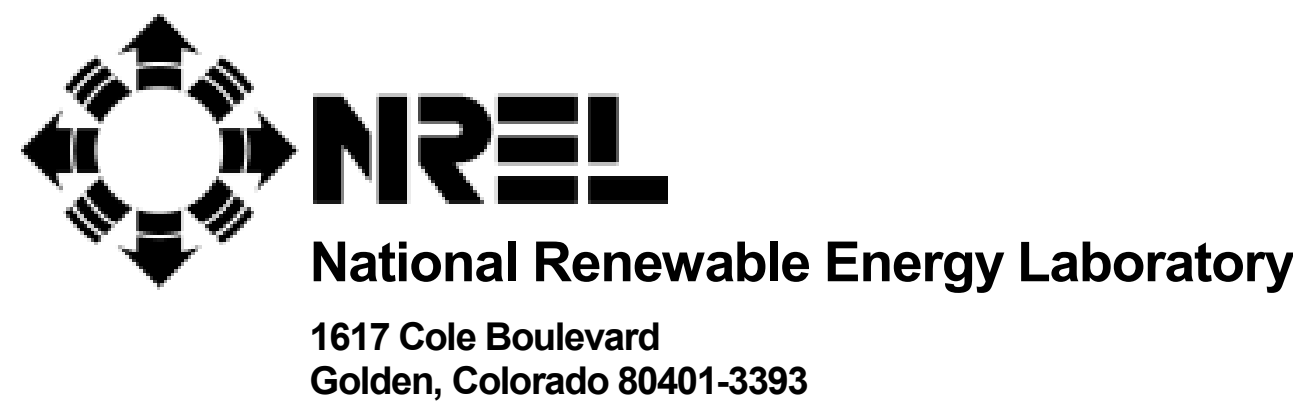

NREL is a U.S. Department of Energy Laboratory

Operated by Midwest Research Institute $\bullet$ Battelle $\bullet$ Bechtel

Contract No. DE-AC36-99-G010337 


\section{NOTICE}

This report was prepared as an account of work sponsored by an agency of the United States government. Neither the United States government nor any agency thereof, nor any of their employees, makes any warranty, express or implied, or assumes any legal liability or responsibility for the accuracy, completeness, or usefulness of any information, apparatus, product, or process disclosed, or represents that its use would not infringe privately owned rights. Reference herein to any specific commercial product, process, or service by trade name, trademark, manufacturer, or otherwise does not necessarily constitute or imply its endorsement, recommendation, or favoring by the United States government or any agency thereof. The views and opinions of authors expressed herein do not necessarily state or reflect those of the United States government or any agency thereof.

Available electronically at http://www.osti.gov/bridge

Available for a processing fee to U.S. Department of Energy

and its contractors, in paper, from:

U.S. Department of Energy

Office of Scientific and Technical Information

P.O. Box 62

Oak Ridge, TN 37831-0062

phone: 865.576.8401

fax: 865.576 .5728

email: reports@adonis.osti.gov

Available for sale to the public, in paper, from:

U.S. Department of Commerce

National Technical Information Service

5285 Port Royal Road

Springfield, VA 22161

phone: 800.553.6847

fax: 703.605.6900

email: orders@ntis.fedworld.gov

online ordering: http://www.ntis.gov/ordering.htm 


\section{Table of Contents}

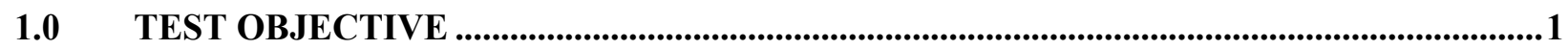

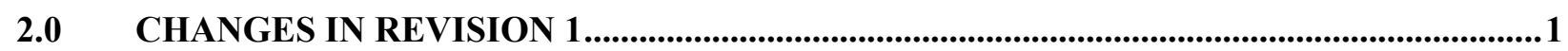

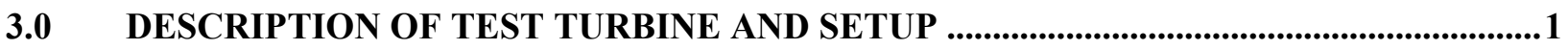

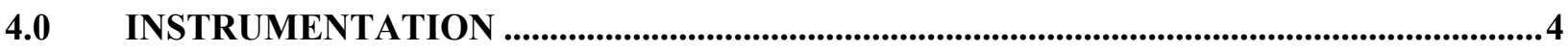

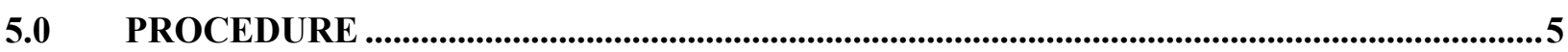

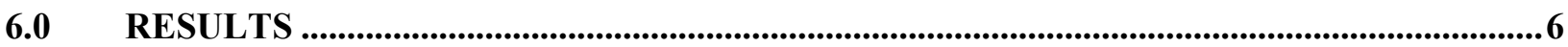

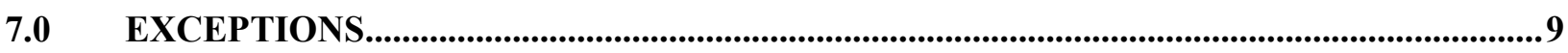

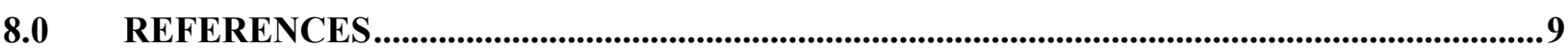

APPENDIX A - INSTRUMENT CALIBRATION SHEETS ............................................................ 10

APPENDIX B - SAFETY AND FUNCTION TEST CHECKLIST ....................................................223 


\subsection{Test Objective}

The objective of this test was to evaluate the safety and function characteristics of the Whisper H40 wind turbine. The general requirements of wind turbine safety and function tests are defined in the IEC standard WT01. The testing was conducted in accordance with the National Wind Technology Center (NWTC) Quality Assurance System, including the NWTC Certification Team Certification Quality Manual and the NWTC Certification Team General Quality Manual for the Testing of Wind Turbines, as well as subordinate documents.

This safety and function test was performed as part of the U.S. Department of Energy's (DOE) Field Verification Program (FVP) for small wind turbines.

\subsection{Changes in Revision 1}

1. Posttest calibrations have been completed on all instrumentation used for this test. Appendix A is expanded to include the post-test calibration certificates and the exception to standard practice is removed.

2. Peak power is now quantified.

3. An estimate of peak rotor speed is now provided.

\subsection{Description of Test Turbine and Setup}

Figure 1 shows the Whisper H40 wind turbine as it was installed at Site 1.3 at the National Wind Technology Laboratory. The Whisper H40 is a three-bladed, upwind, variable-speed turbine that uses furling for power regulation and overspeed control. The turbine is mounted on a 10-cm (4-in.) tube tower at a hub height of $9.1 \mathrm{~m}(30 \mathrm{ft})$. The tilt-down tower is supported by four guy wires and can be easily lowered to ground level for turbine inspection and maintenance.

The turbine uses a direct-drive, permanent magnet, brushless alternator to produce three-phase, variable-frequency, variable-voltage, AC power. This "wild AC" power is directed through slip rings in the nacelle to the turbine's EZWIRE controller.

The EZWIRE is a proprietary, silicon controlled rectifier (SCR) and features turbine control and a dump load. In this test, it was configured to produce 24 volts DC. The voltage is stabilized with four batteries. A Trace sine-wave inverter (model number SW4024) converts the DC power to 120 volts $\mathrm{AC}$ and feeds it to the NWTC electrical grid. In case of a utility outage or inverter failure, the resistive dump load dissipates energy from the turbine. A manual switch provides braking for the turbine by disconnecting it from the load and shorting two of the generator leads together. The arrangement of these components is shown in Figure 2.

Table 1 lists configuration and operational data for the Whisper $\mathrm{H} 40$.

The Whisper H40 wind turbine was tested at Site 1.3 of the NWTC (hereafter referred to as the test site), approximately $8 \mathrm{~km}(5 \mathrm{mi})$ south of Boulder, Colorado. The site is located in somewhat complex terrain at an approximate elevation of $1850 \mathrm{~m}(6070 \mathrm{ft})$ above sea level. 
Table 1. Test Turbine Configuration and Operational Data

\begin{tabular}{|c|c|}
\hline \multicolumn{2}{|l|}{ General Configuration: } \\
\hline Make, model, serial number & World Power Technologies, Whisper H40, 09092256 \\
\hline Rotation axis & Horizontal \\
\hline Orientation & Upwind \\
\hline Number of blades & 3 \\
\hline Rotor hub type & Rigid \\
\hline Rotor diameter $(\mathrm{m})$ & 2.1 \\
\hline Hub height (m) & 9.1 \\
\hline \multicolumn{2}{|l|}{ Performance: } \\
\hline Rated electrical power $(\mathrm{kW})$ & 0.9 \\
\hline Rated wind speed (m/s) & 12.5 \\
\hline Cut-in wind speed $(\mathrm{m} / \mathrm{s})$ & 3.4 \\
\hline \multicolumn{2}{|l|}{ Rotor: } \\
\hline Swept area $\left(\mathrm{m}^{2}\right)$ & 3.6 \\
\hline Cut-in rotational speed (rpm) & 300 \\
\hline Maximum rotational speed (rpm) & 1,200 \\
\hline Tilt angle (deg) & 7 \\
\hline Blade pitch angle (deg) & 0 (nonlinear $13^{\circ}$ at root to $1^{\circ}$ at tip) \\
\hline Direction of rotation & $\mathrm{CCW}$ \\
\hline Overspeed control & Furling \\
\hline \multicolumn{2}{|l|}{ Braking System: } \\
\hline Electrical brake: make, type, location & Three-phase, short-circuit brake \\
\hline \multicolumn{2}{|l|}{ Yaw System: } \\
\hline Wind direction sensor & Tail vane \\
\hline \multicolumn{2}{|l|}{ Tower: } \\
\hline Type & Guyed tube tilt-down \\
\hline Height $(\mathrm{m})$ & 9.1 \\
\hline \multicolumn{2}{|l|}{ Control / Electrical System: } \\
\hline Controller: make, type & EZWIRE system 120 SW4024 \\
\hline Power converter: make, type & Trace \\
\hline $\begin{array}{l}\text { Electrical output: voltage, frequency, } \\
\text { number of phases }\end{array}$ & $480 \mathrm{VAC}, 60 \mathrm{~Hz}, 1-$ phase \\
\hline
\end{tabular}




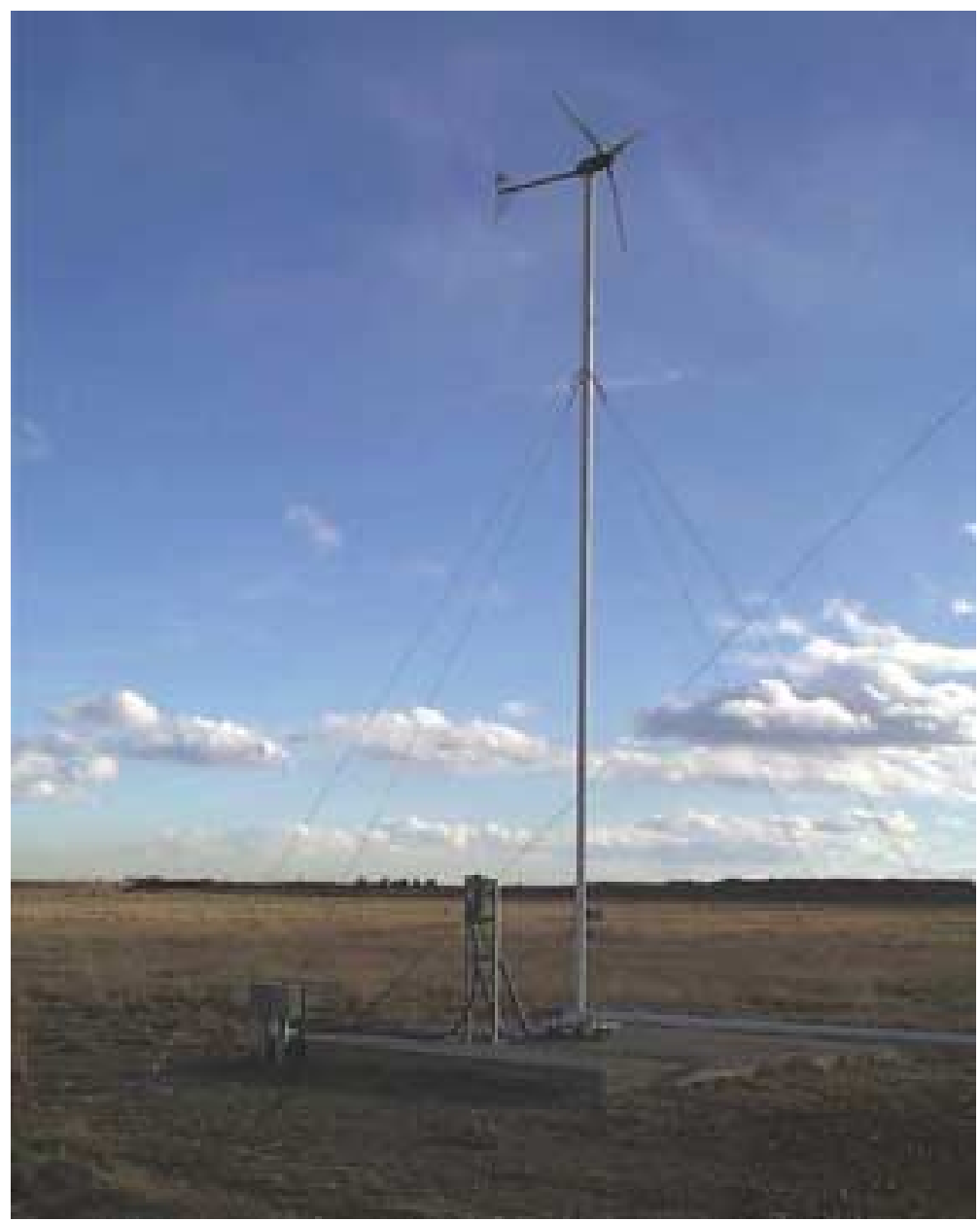

Figure 1. Whisper H40 turbine at the NWTC test site. 


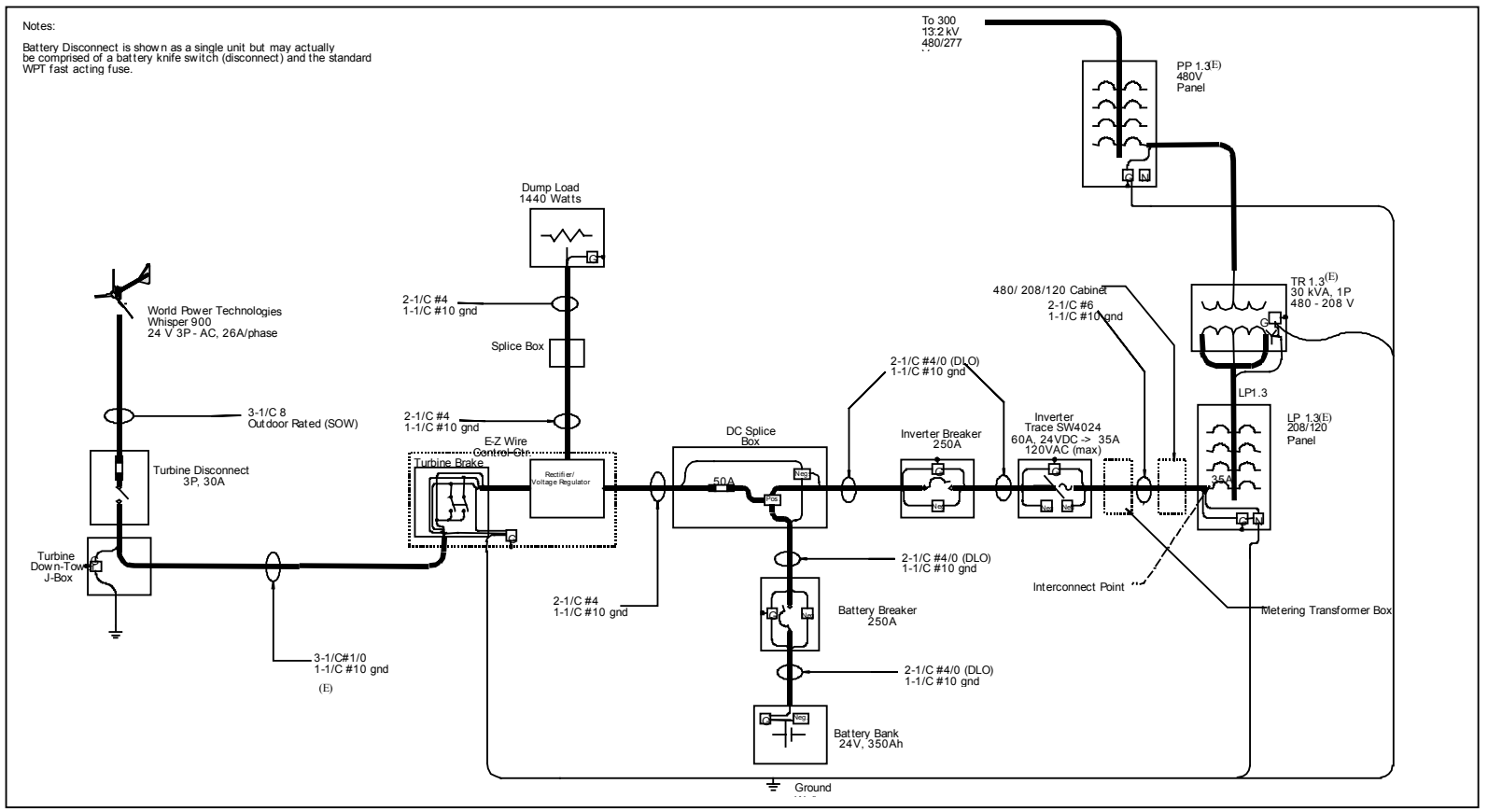

Figure 2. Electrical one-line drawing.

\subsection{Instrumentation}

The following parameters were measured in this test: wind speed, DC bus voltage, DC bus current, $\mathrm{AC}$ power, and rotor speed. In planning for the test, we expected to measure current to the dump load. However, during the test, current to the dump load was not measured. It was determined from heating of the dump load resistors that the dump load function was suitable. The instruments that were used for these measurements are listed in Table 2. The calibration sheets for the instruments used for this safety and function test are included in Appendix A.

Table 2. Equipment List for Safety and Function Test

\begin{tabular}{|l|l|}
\hline AC Power Transducer \\
\hline Make/model: & OSI, GWV5-001EY24/1 \\
\hline $\begin{array}{l}\text { Serial number (power } \\
\text { transducer/current transducers): }\end{array}$ & 0010301 \\
\hline Range with CTs: & $0-+/-1$ \\
\hline Calibration due date: & $1 / 5 / 01$ \\
\hline Turbine Speed & Action Pak \\
\hline Make/model: & B7YSV \\
\hline Serial number: & $0-1000 \mathrm{rpm}$ \\
\hline CT range: & $2 / 18 / 01$ \\
\hline Calibration due date: & OSI VT7-003E \\
\hline DC Bus Voltage & 4 \\
\hline Make/model: &
\end{tabular}




\begin{tabular}{|l|l|}
\hline Serial number: & 9111995 \\
\hline CT range: & $0-50 \mathrm{Vdc}$ \\
\hline Calibration due date: & $1 / 3 / 01$ \\
\hline DC Bus Current & OSI CTA212 \\
\hline Make/model: & 0010126 \\
\hline Serial number: & $0-50 \mathrm{Amp}$ \\
\hline CT range: & $1 / 3 / 01$ \\
\hline Calibration due date: & Met One, $010 \mathrm{C}$ with aluminum cups \\
\hline Met Anemometer $\mathbf{2 / 9 / 2 0 0 0}$ to 11/29/2000 \\
\hline Make/model: & W1231 \\
\hline Serial number: & $2 / 9 / 01$ \\
\hline Calibration due date: & $6.7 \mathrm{~m}$ upwind \\
\hline Met tower location: & Met One, $010 \mathrm{C}$ with aluminum cups \\
\hline Met Anemometer 11/29/2000 to 7/30/2001 \\
\hline Make/model: & W1240 \\
\hline Serial number. & $4 / 21 / 01$ \\
\hline Calibration due date: & 6.7 m upwind \\
\hline Met tower location: & Campbell Scientific CR21X \\
\hline Datalogger $\mathbf{2 / 1 5 / 2 0 0 0 ~ t o ~} \mathbf{1 0 / 4 / 2 0 0 0}$ \\
\hline Make/model: & 13185 \\
\hline Serial number: & Postcalibration on 2/8/2001 \\
\hline Calibration due date: & Campbell Scientific CR23X \\
\hline Datalogger 10/4/2000 to 7/31/01 & 3099 \\
\hline Make/model: & $8 / 30 / 2001$ \\
\hline Serial number: & \\
\hline Calibration due date: & \\
\hline
\end{tabular}

\subsection{Procedure}

The requirements for a safety and function test as described in Annex D of IEC WT01 [1] are:

"The plan for the safety and function tests shall include the critical functions of the control and protection system that require test verification, as described in the design documentation. These critical functions shall at least include:

- emergency shutdown during operation;

- power and speed control;

- yaw control (including cable twist);

- operating vibration levels and excessive vibration protection ;

- grid loss behavior;

- over speed protection at rated wind speed or above; and

- start-up and shutdown above rated wind speed.

Any additional protection system function that may be activated by component failure or other critical events or operational conditions shall also be tested. This testing may include simulation of the critical event or operational condition. Each test shall be described in the test plan. In many cases, several component failure modes or critical events will lead to similar behavior of the control and protection system and may be covered by a single test. The Certification Body shall verify that the tests described in the test plan cover all identified critical control and protection system functions." 
For the Whisper, this led to a number of tests, the procedures of which are given in Appendix B.

\subsection{Results}

The turbine exhibited no unexpected or inherently unsafe behavior. However, this does not mean that the turbine is safe. The tests considered only those conditions in which the turbine control and protection system was expected to maintain the turbine in a safe condition. In some failure modes, such as a failure of the dump load when the grid is not available, the response was expected to result in overcharging, damage, and possible fire in the battery bank. NREL does not judge whether such failures are likely or whether additional features in the control and protection system are needed to protect against such consequences.

\section{Yaw Orientation}

Observations have been made of the turbine over the last year, including during acoustic noise tests taken over a wide wind speed range [4-22 m/s (9-49 mph)] and on different dates (January 4 and 25, 2001, and February 5, 2001). No abnormal behavior has been noticed. The wind turbine seems to track the wind pretty accurately.

\section{Power Limitation}

DC current and voltage were measured throughout the duration test and the data used to determine the maximum observed and the maximum expected power in winds below $50 \mathrm{~m} / \mathrm{s}(112 \mathrm{mph})$. Maximum DC power is calculated from the maximum 1-sec measurement of DC current multiplied by the maximum, 1-sec measurement of DC voltage for each 10-minute period. There is some error in this method because maximum current and voltage may have occurred at different times during the 10minute period. However, DC voltage was maintained very closely by the inverter so errors are expected to be low. Figure 3 shows a plot of average and maximum 1-sec DC power versus the maximum 1-sec wind speed. The figure indicates that maximum 1-sec power would be limited to less than $1,300 \mathrm{~W}$ in winds less than $50 \mathrm{~m} / \mathrm{s}(112 \mathrm{mph})$.

\section{Rotor Speed Limitation}

Rotor speed was measured throughout the duration test. However, toward the end of the test, NREL noted that a frequency to voltage transducer used in the measurement system was improperly set. This resulted in the rotor speed signal being clipped at 1,100 rpm as shown in Figure 4. Thus it was not possible to directly determine whether rotor speed is properly limited by the furling mechanism. However, rotor speed is well correlated with DC power over the range of operation in which the signal was not distorted, as shown in Figure 5. Using this correlation and extrapolating this to the highest measured instantaneous power level of approximately 1,300 W, NREL estimates that rotor speed does not exceed 1,600 rpm in winds below $50 \mathrm{~m} / \mathrm{s}(112 \mathrm{mph})$. Because of the uncertainty in the correlation of power and rotor speed outside of the observed range of operation, this estimate may not be conservative.

\section{Brake Operation}

During the noise tests, the brake was applied several times at different wind speeds. The brake worked in wind speeds up to $6-7 \mathrm{~m} / \mathrm{s}(13.4-15.7 \mathrm{mph})$. The typical braking procedure is to wait for a lull in the wind speed (noted by a dip in the produced current) to engage the stop switch, and, if the turbine does not stop directly, to release the brake to prevent overheating of the alternator. If there is a long enough dip in the wind speeds, the turbine can be braked at relatively high wind speeds [up to $10 \mathrm{~m} / \mathrm{s}$ (22.4 mph)]. The Whisper H40 manual indicates that the brake only works in moderate wind speeds when the turbine is not furled. The observed behavior is consistent with the manual. 


\section{Grid Outage}

On June 25, at wind speeds between 6 and $11 \mathrm{~m} / \mathrm{s}$ (13.4 and $24.6 \mathrm{mph})$, the batteries were disconnected and the inverter was shut down. After a minute the LED on the EZWIRE setting "REGULATING" began switching on and off. After a few minutes the dump load became hot. The configuration was maintained for 10 minutes, after which the inverter and batteries were connected again. No damage to the dump load was observed.

\section{Battery Disconnect}

The batteries were disconnected in winds of 6-11 m/s (13.4-24.6 mph). No change in turbine behavior was heard or otherwise observed. The produced power went to the grid.

\section{Loss of Load}

Tests were done with one, two, and three turbine phases disconnected from the EZWIRE. As described above, the measured rpm signal was clipped. In addition, the correlation between rotor speed and power is not applicable to loss of load events. Thus no rpm data can be shown for this test. Observations indicated that under loss of load, the turbine still furled in a manner consistent with its operation under load. However, the blades occasionally fluttered at winds of about $15 \mathrm{~m} / \mathrm{s}(34 \mathrm{mph})$, indicating that rotor speed was higher than during normal operation.

In addition, after the winds died, the turbine appeared to be stuck in furl (about $20^{\circ}-30^{\circ}$ furl angle). This seemed to be related to the furling problem that was observed earlier during the duration test. Uptower inspection showed excessive friction in the furl bearing. This behavior did not appear to be caused by the loss of load.

\section{Unauthorized Changing of Control Settings}

A knob on the front panel of the EZWIRE can be used to set the charge voltage of the batteries. This is used to equalize flooded lead acid batteries. However, turning this knob to high-charge settings might cause danger for gel and agm batteries.

\section{Failure in Furl System}

The turbine was locked in an unfurled position using hose clamps. During the measurement period, winds were not high enough to have normally caused the turbine to furl.

\section{Electrical Safety}

All major electrical components are behind doors that can only be opened with a screwdriver or other tool. Further stickers warn for high voltages, multiple source, etc.

\section{Lighting Protection}

The turbine has no special lightning protection system. In the case of the turbine at the NWTC, the base plate of the tower is grounded, but the tower alone is not. The guy wires are also not grounded. 


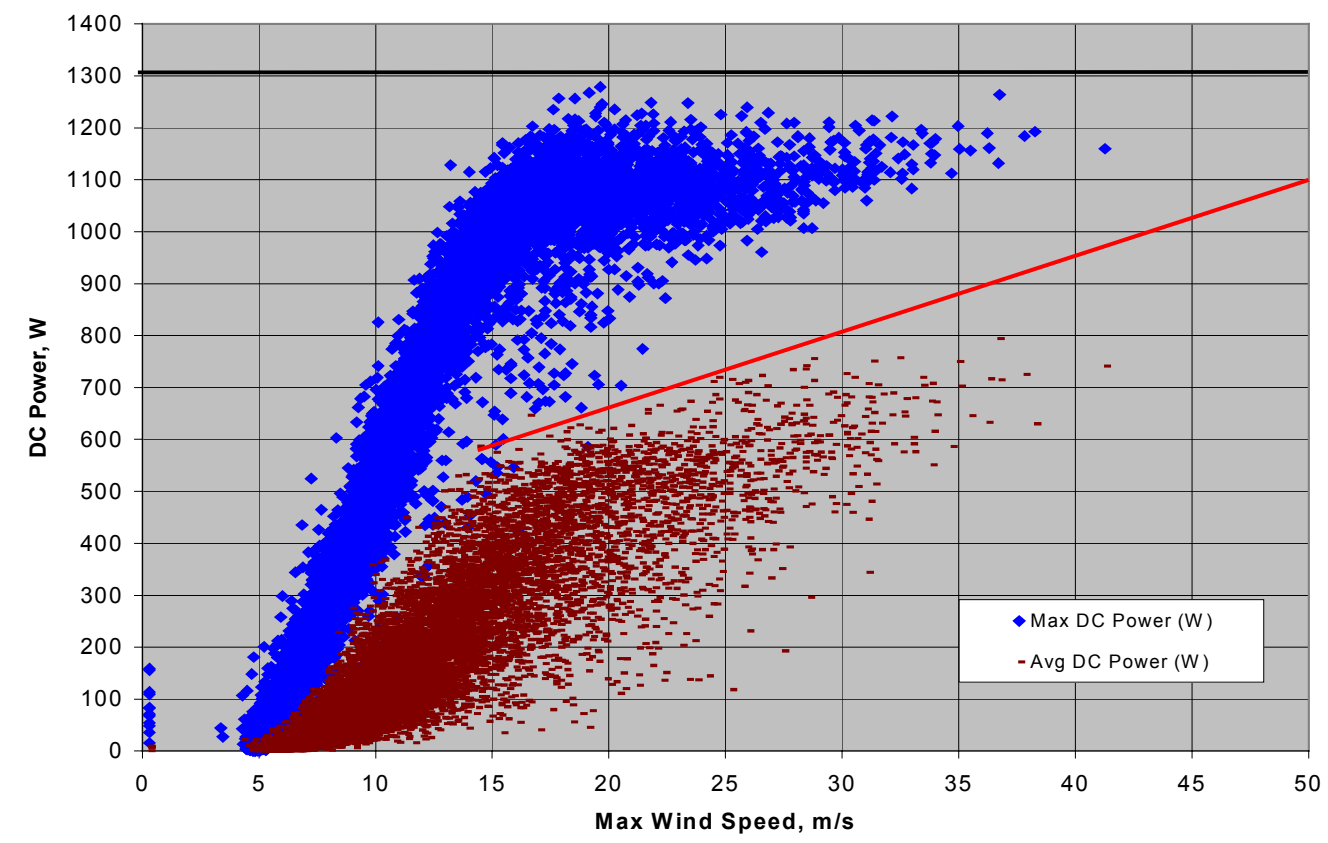

Figure 3. Whisper H40 power response to wind speed.

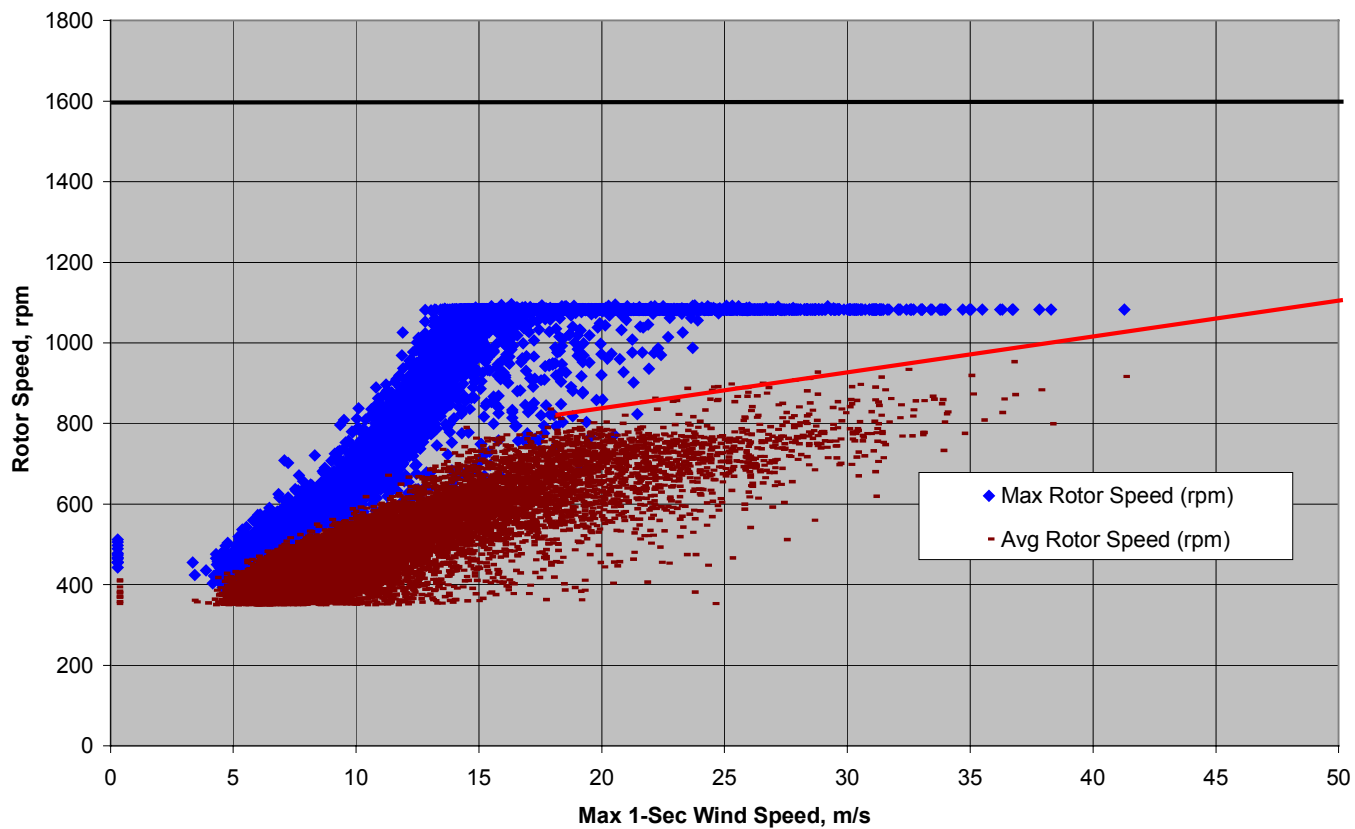

Figure 4. Whisper $\mathrm{H} 40$ rotor speed response to wind speed. 


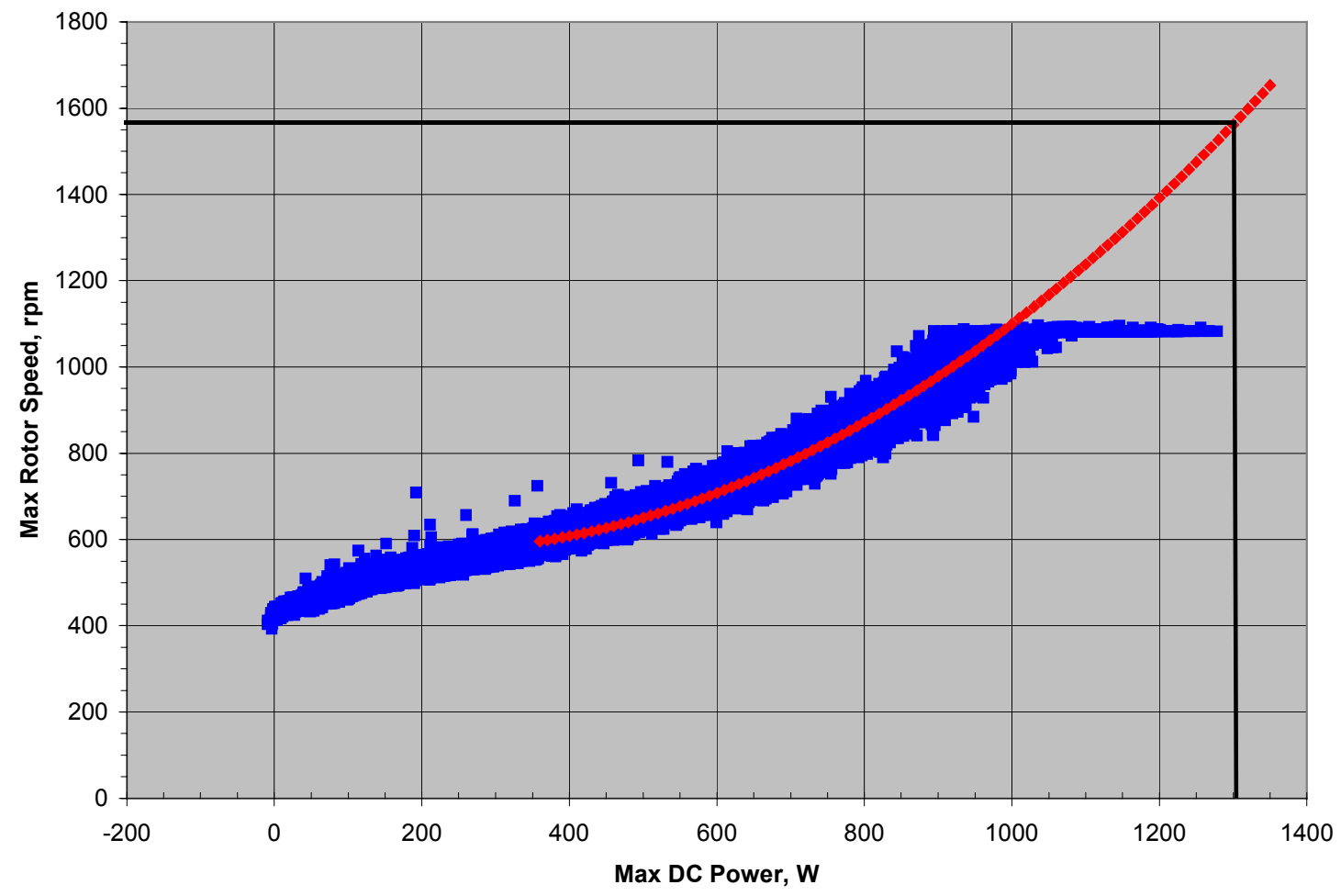

Figure 5. Relationship of Whisper H40 rotor speed to power.

\subsection{Exceptions}

None

\subsection{References}

[1] IEC WT 01 "IEC System for Conformity Testing and Certification of Wind Turbines - Rules and Procedures" First Edition; 2001-04, International Electrotechnical Committee. 
Appendix A - Instrument Calibration Sheets 


\section{- \\ OSI OHIO SEMITRONICS, INC. \\ 4242 REYNOLDS DRIVE - HILLIARD, OHIO 43026 \\ Telephone (614) 777-1005 \\ FAX (614) 777-4511}

CERTIFICATE OF COMPLIANCE

MODEL GWV5-001EY37

COMPANY NREL

SERIAL NO.

0010301

PO\# $\frac{\text { J BIANCHI }}{\text { OSI PO\# } 48881}$ RMA\# NA
DATE $1-5-00$

It is hereby certified, that all articles in the quantities as called for on the above order are in conformance with all applicable requirements and specifications as outlined in that order and any negotiated changes related thereto.

Accuracy has been established by comparison with standards traceable to the National Institute of Standards and Technology.

EQUIPMENT USED:

MFG

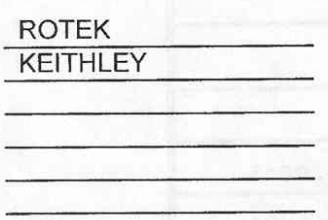

ABOVE EQUIPMENT IS TRACEABLE TO

MFG

ROTEK

ROTEK

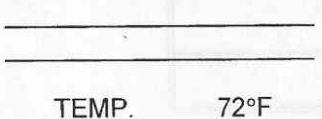

TEMP. $\quad 72^{\circ} \mathrm{F}$

HUM.

$55 \%$

Dwg. \#A-7003-02

MODEL
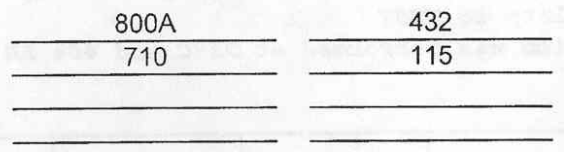

CAL.

DATE

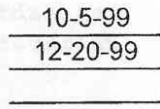

OHIO SEMITRONICS, INC.

Company

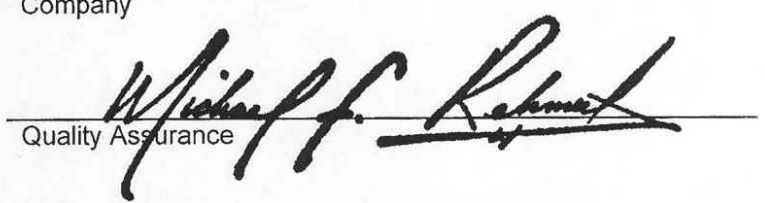

THE LEADER IN POWER MEASUREMENT 


\section{NREL METROLOGY ILABORATORY \\ Test Report}

Test Instrument: Transducer

Model \#
: GWV5-001EY37
DOE \#: $02747 C$

$S / N=0010301$

Due Date: 08/09/2003

Calibration Date: 08/09/2001

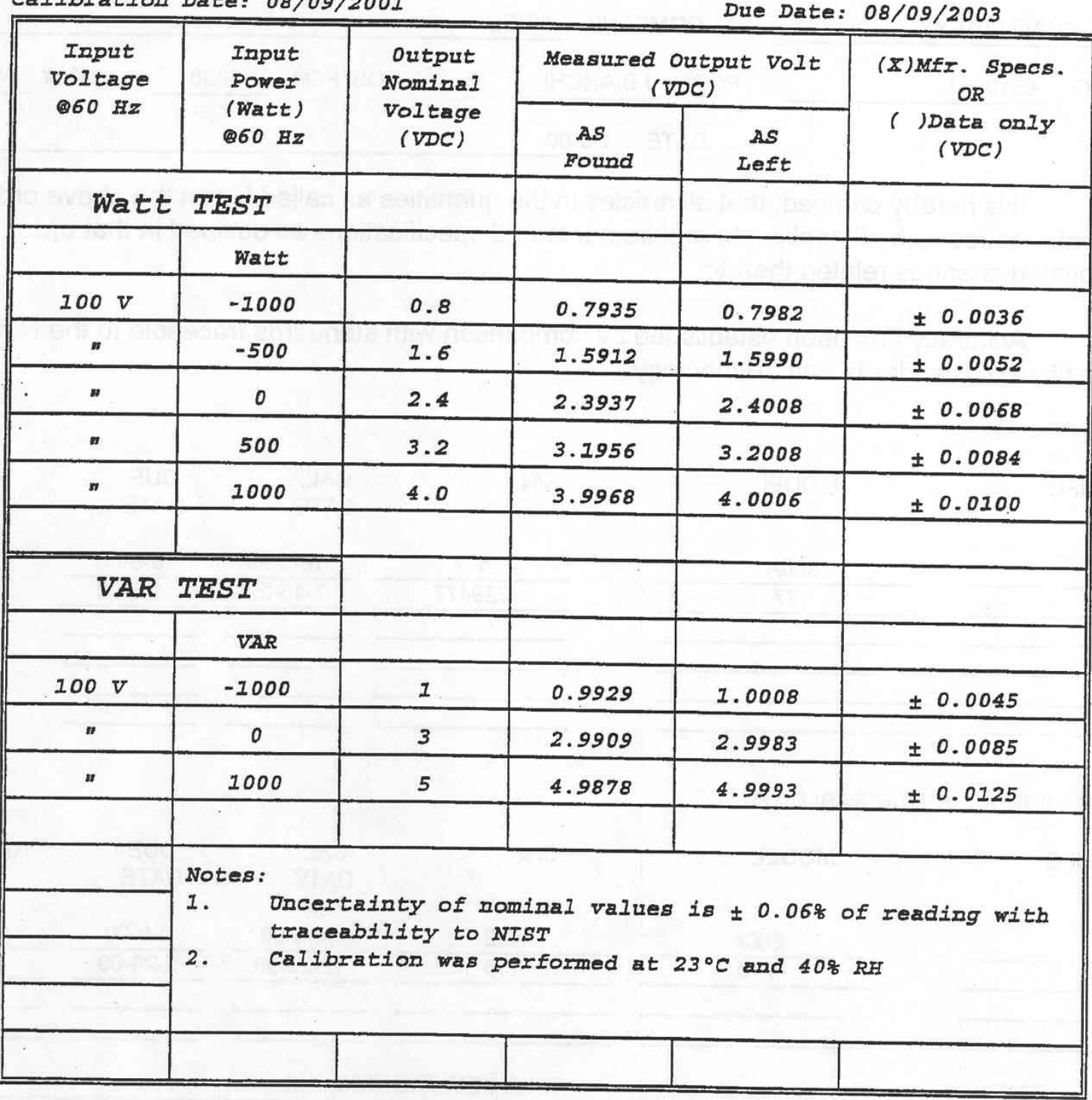

Tested BY: Reda

Date : 08/09/2001 


\title{
Frequency Converter Calibration
}

\author{
Date Calibrated: \\ $2 / 18 / 2000$ \\ Report No: \\ F-to-V B2MCD 000218 \\ Calibration Laboratory: \\ National Renewable Energy Laboratory \\ 1617 Cole Blvd \\ Golden, CO 80401 \\ Cal Location: \\ National Wind Technology Center \\ 18200 State Hwy 128 \\ Boulder, CO 80303 \\ Technician: \\ Mark Meadors

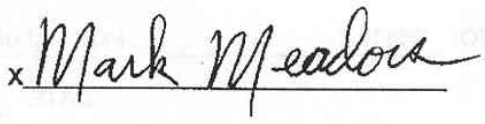 \\ Frequency Source: \\ $\mathrm{S} / \mathrm{N}$ : \\ Calibrated by: \\ Date: \\ Cal Due: \\ Fluke Documenting Process Calibrator, Model 743B \\ 6965608 \\ Instrument Repair Labs \\ 10/12/1999 \\ $10 / 12 / 2000$ \\ Voltage Measurement: \\ S/N: \\ Campbell Scientific Model 23X Datalogger \\ 1214 \\ Campbell Scientific \\ 2/7/2001 \\ $2 / 7 / 2002$ \\ Cal Due: \\ Ultra Slim Pack Frequency Input, Field Configurable Isolator \\ G478-0001 \\ B7YSV \\ GI27 010227, Calibrate frequency to voltage devices \\ Calibration Method: \\ Good \\ Device Condition: \\ Calibration Uncertainty:

$\begin{array}{lll}0.1 & \text { hertz } & \text { Fluke Calibrator for freq: } 11<\mathrm{hz}<110 \\ 0.5 & \text { hertz } & \text { Fluke Calibrator for freq: } 110<\mathrm{hz}<1100 \\ 5.0 & \mathrm{mv} & \text { Campbell Datalogger for volt: } 0<v<5 \\ 48.1 & \mathrm{rpm} / \mathrm{mv} & \text { Sensitivity Factor for Campbell } \\ 240.5 & \mathrm{rpm} & \text { Campbell Uncertainty in rpm }\end{array}$ \\ Special Limitations: $\quad$ 0-150 Vac input, 4-20 mA output with $250 \mathrm{ohm}, .01 \%, 0.6 \mathrm{ppm} / \mathrm{deg} \mathrm{C}$ IR \\ Calibration Factors: \\ RPM - to - Voltage Conversion \\ 10-pole alternator

$\begin{array}{llll}\text { Slope: } & 0.0208 & \mathrm{mV} / \mathrm{hz} & 0.24952 \mathrm{mV} / \mathrm{rpm} \\ \text { Offset: } & -20.700 & \mathrm{hz} & -248.39 \mathrm{rpm}\end{array}$


[OSI] OHIO SEMITRONICS, INC.

4242 REYNOLDS DRIVE - HILLIARD, OHIO 43026

Telephone (614) 777-1005

FAX (614) 777-4511

\author{
CERTIFICATE OF COMPLIANCE
}

MODEL VT7-003E

COMPANY NREL

SERIAL NO. 1995

PO\# $\frac{\text { J BIANCHI }}{\text { DATE } 1-3-00}$ OSI PO\# 48881 RMA\# NA

It is hereby certified, that all articles in the quantities as called for on the above order are in conformance with all applicable requirements and specifications as outlined in that order and any negotiated changes related thereto.

Accuracy has been established by comparison with standards traceable to the National Institute of Standards and Technology.

EQUIPMENT USED:

MFG

MODEL

$S / N$

CAL. DUE
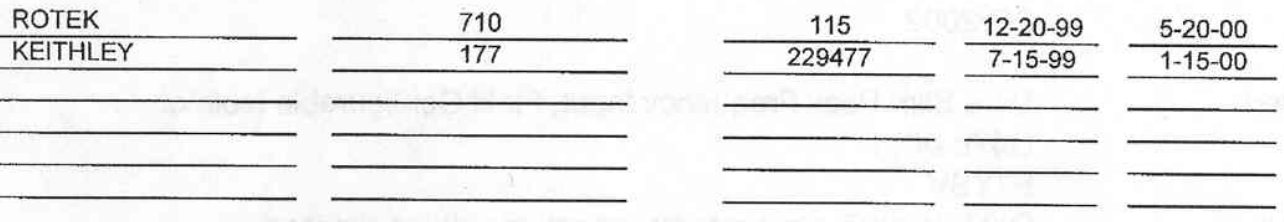

ABOVE EQUIPMENT IS TRACEABLE TO:

MFG

\section{ROTEK}

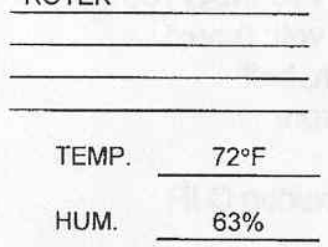

Dwg. \#A-7003-02
MODEL
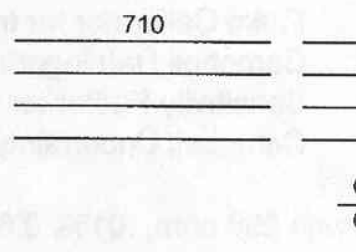

$\mathrm{S} / \mathrm{N}$

CAL.

DATE

DUE REPORT

115

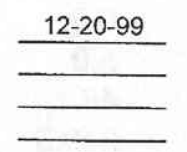

21054

OHIO SEMITRONICS, INC

Company

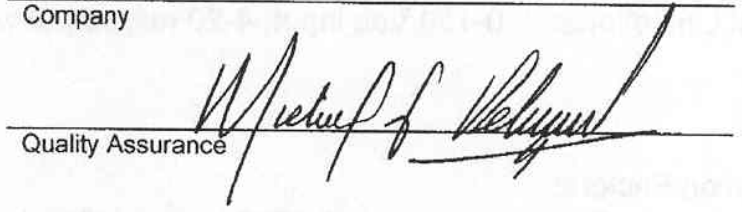

THE LEADER IN POWER MEASUREMENT 
NREL METROLOGY LABORATORY

Test Report

Test Instrument: Transducer
ModeI \# : VT7-003E
Calibration Date: 08/09/200I

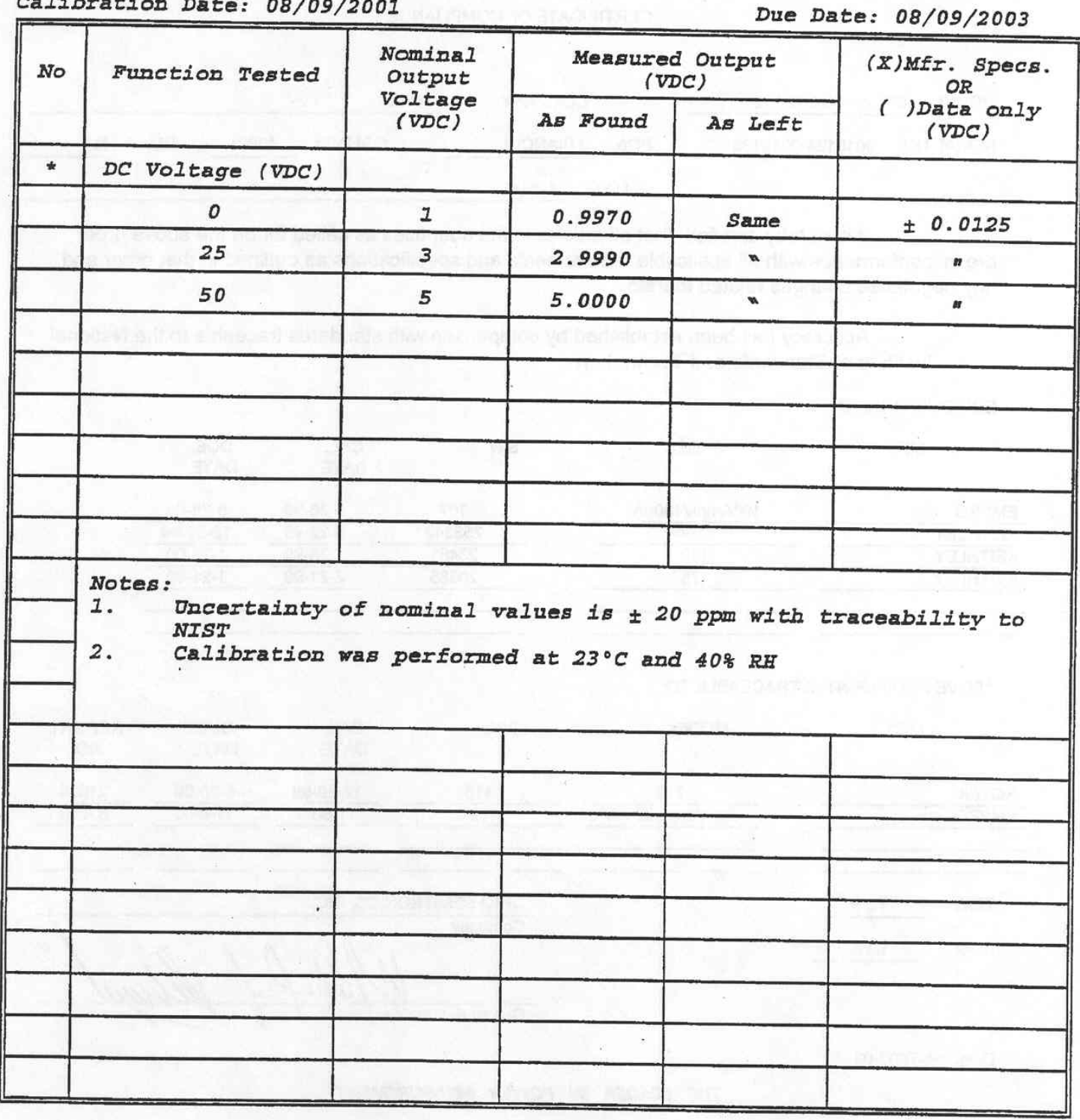

Tested By: Reda

Date

: 08/09/2001 


\section{[OSI] OHIO SEMITRONICS, INC.}

4242 REYNOLDS DRIVE HILLIARD, OHIO 43026

Telephone (614) 777-1005

FAX (614) $777-4511$

CERTIFICATE OF COMPLIANCE

\begin{tabular}{l} 
MODEL CTL-51/50-CTA212 \\
SERIAL NO. $0010124-0010126$ \\
\hline
\end{tabular}

\begin{tabular}{|c|c|c|c|c|c|}
\hline & COMPANY & NRELL & & & \\
\hline PO\# & J BIANCHI & OSI PO\# & 48881 & RMA\# & NA \\
\hline
\end{tabular}

It is hereby certified, that all articles in the quantities as called for on the above order are in conformance with all applicable requirements and specifications as outlined in that order and any negotiated changes related thereto.

Accuracy has been established by comparison with standards traceable to the National Institute of Standards and Technology.

EQUIPMENT USED:

MFG

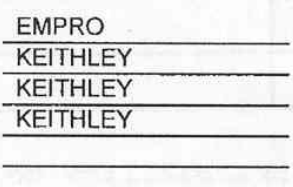

ABOVE EQUIPMENT IS TRACEABLE TO:

ROTEK

EMPRO

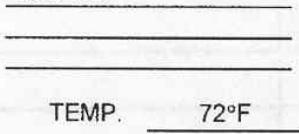

HUM.

$63 \%$

Dwg. \#A-7003-02

MODEL

MODEL
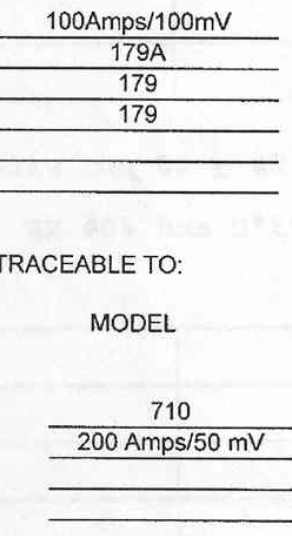

$$
\begin{array}{ccc}
\text { S/N } & \text { CAL. } & \text { DUE } \\
\text { DATE } & \text { DATE }
\end{array}
$$

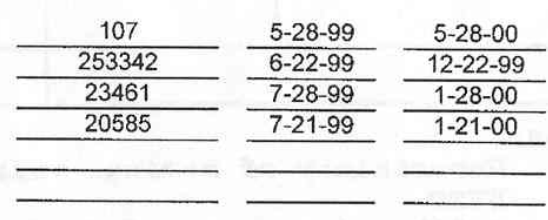

$\mathrm{S} / \mathrm{N}$

$$
\text { CAL. }
$$

DATE

DUE

DATE

REPORT

NO.

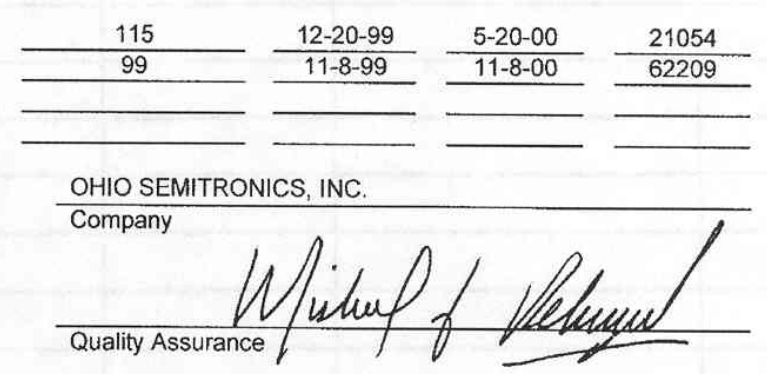

THE LEADER IN POWER MEASUREMENT 


\section{NREL METROLOGY IAABORATORY}

Test Report

Test Instrument: Signal Conditioner

ModeI \# : CTA212

DOE \#: $02749 C$

Calibration Date: 08/09/2001

$S / N: 0010126$

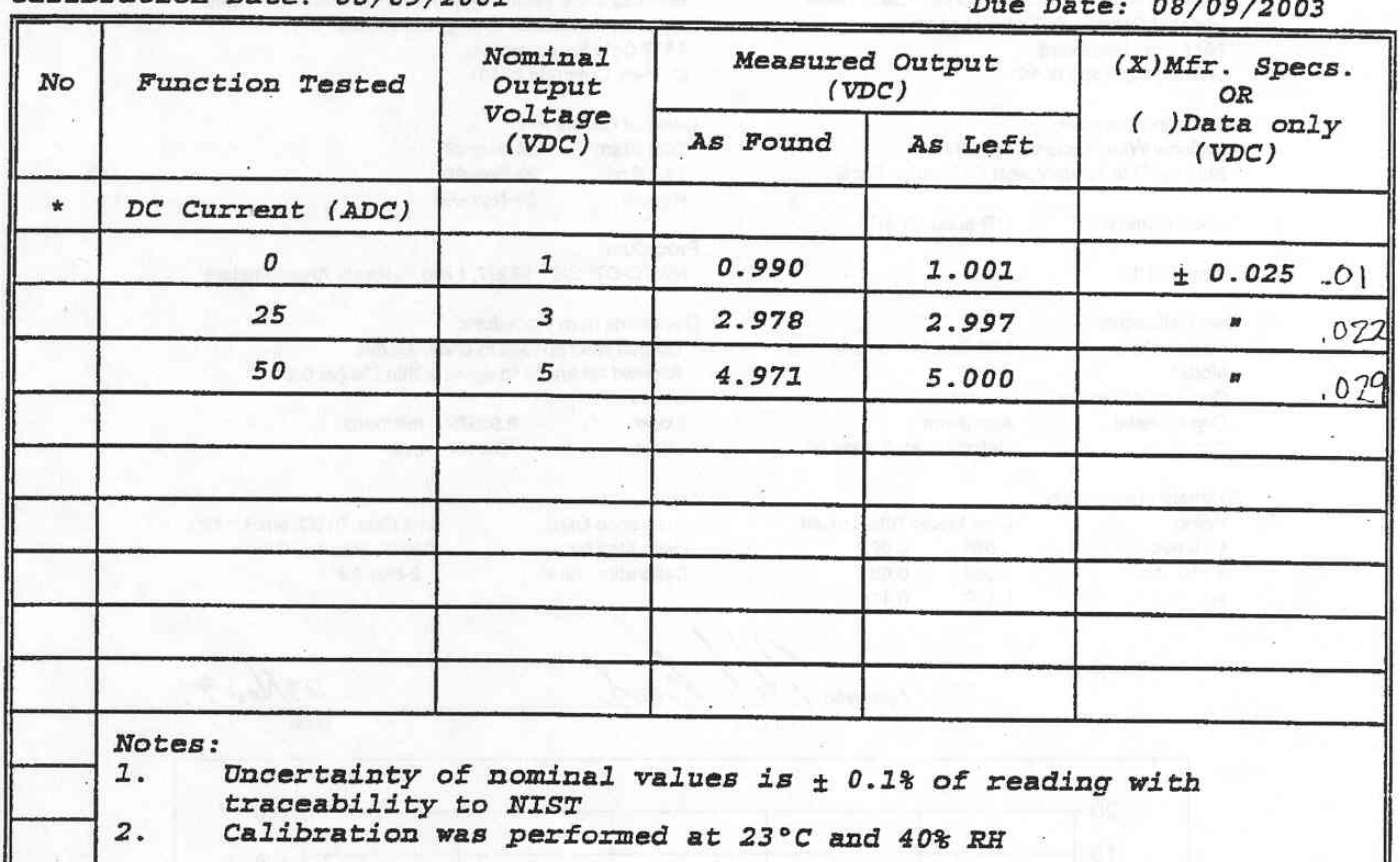

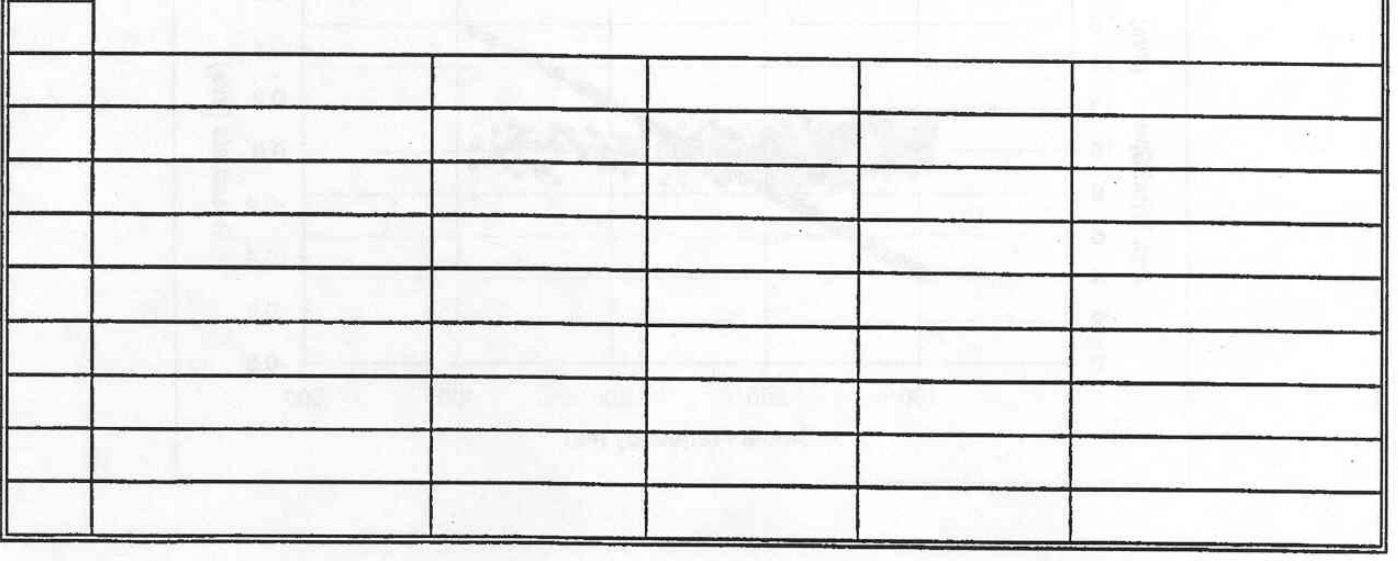

Tested BY: Reda

Date

: 08/09/2001 
Serial number: W1231

\section{Anemometer Calibration Report}

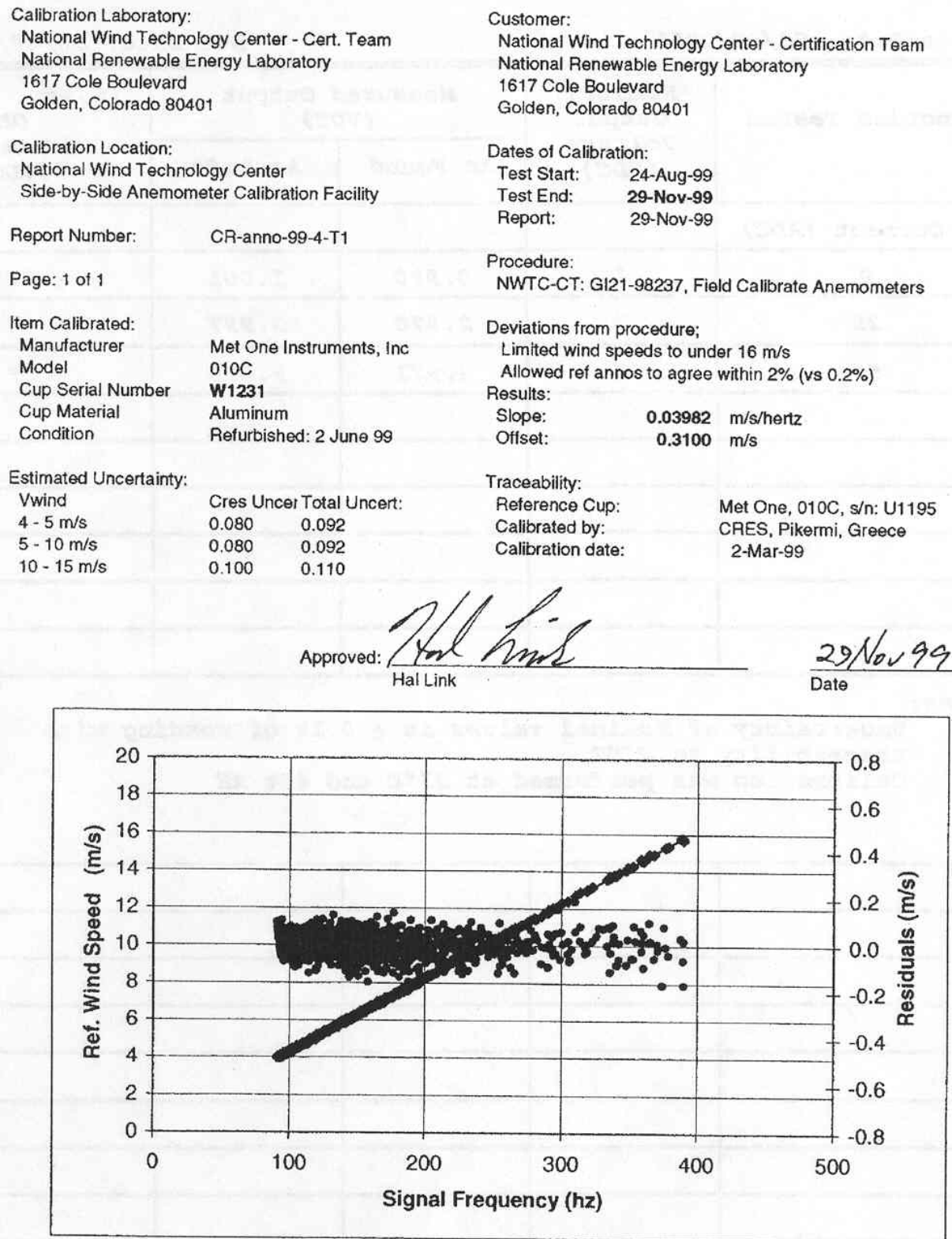


Serial number: W1240

\section{Anemometer Calibration Report}

Calibration Laboratory:

National Wind Technology Center - Cert. Team

National Renewable Energy Laboratory

1617 Cole Boulevard

Golden, Colorado 80401

Calibration Location:

National Wind Technology Center

Side-by-Side Anemometer Calibration Facility

Report Number:

CR-anno-99-5-T4

Page: 1 of 1

\begin{tabular}{|c|c|c|}
\hline \multicolumn{3}{|l|}{ tem } \\
\hline Manufacturer & \multicolumn{2}{|c|}{ Met One Instruments, Inc } \\
\hline Model & \multicolumn{2}{|c|}{$010 \mathrm{C}$} \\
\hline Cup Serial Number & \multicolumn{2}{|c|}{ W1240 } \\
\hline Cup Material & \multicolumn{2}{|c|}{ Aluminum } \\
\hline Condition & \multicolumn{2}{|c|}{ Refurbished: 5 May 99} \\
\hline \multicolumn{3}{|l|}{ Estimated Uncertainty: } \\
\hline Vwind & \multicolumn{2}{|c|}{ Cres Uncer Total Uncert: } \\
\hline $4.5 \mathrm{~m} / \mathrm{s}$ & 0.080 & 0.090 \\
\hline $5.10 \mathrm{~m} / \mathrm{s}$ & 0.080 & 0.090 \\
\hline $10.15 \mathrm{~m} / \mathrm{s}$ & 0.100 & 0.109 \\
\hline
\end{tabular}

Customer:

National Wind Technology Center - Certification Team

National Renewable Energy Laboratory

1617 Cole Boulevard

Golden, Colorado 80401

Dates of Calibration:

Test Start: 23-Dec-99

Test End: 10-Jan-00

Report: 10-Jan-00

Procedure:

NWTC-CT: Gl21-98237, Field Calibrate Anemometers

Deviations from procedure;

Limited wind speeds to under $16 \mathrm{~m} / \mathrm{s}$

Allowed ref annos to agree within $2 \%$ (vs $0.2 \%$ )

Results:

Slope:

Offset:

$0.04002 \mathrm{~m} / \mathrm{s} /$ hertz

0.3288

Traceability:

Reference Cup:

Calibrated by:

Calibration date:

Met One, 010C, s/n: T235

CRES, Pikermi, Greece 2-Mar-99
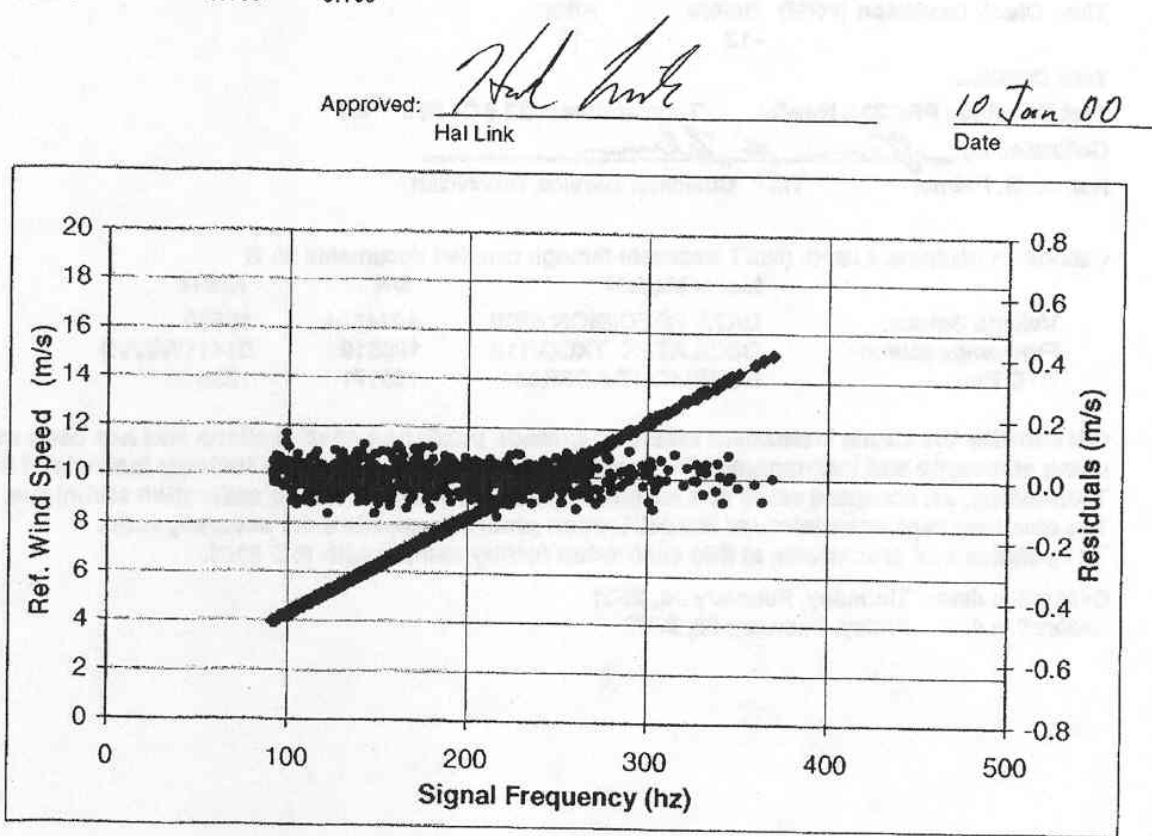


\section{X Callbration Report}

Datalogger Typo:21X Serlal Number: 13185 RMAll: 3059 Contract

Whan Recelved, this instrument was found as follows:

In Toleranoe:

Out of tolerance

Operational failure: (No incoming tolerance declared)

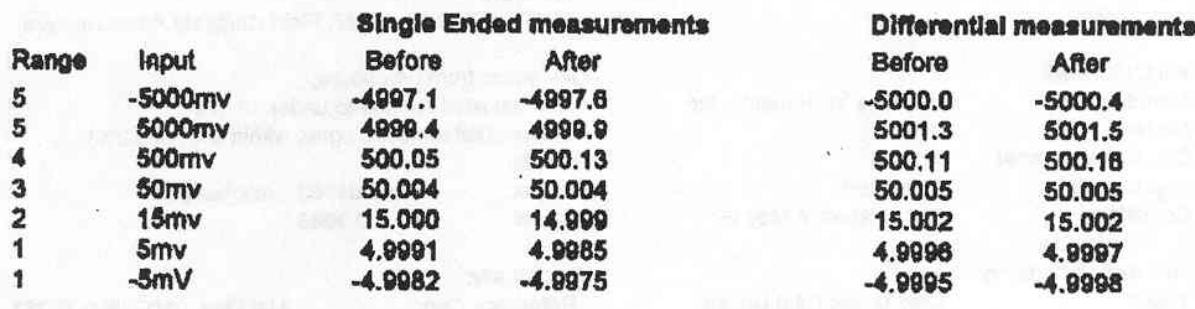

Note: $\mathrm{X}=$ Out of folerance

Time Clock Dovlation (PPM) Eofore

$-12$
After

$-10$

Test Dotall a..

Test DocRev.: PRC23A Rovi24 Temperature: 22.5C RH: 9.1

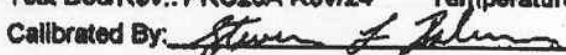

Name: S. Polmer Title: Customer Senvice Techniclan

Callbration equipment used: (NIST traceable through certifled documents on fil

$\begin{array}{llll} & \text { Mlake/ Model* } & \text { SN } & \text { NIST: } \\ \text { Voltage source: } & \text { DATA PRECISION 8200 } & \text { A014824 } & 10598 \\ \text { Frequency source } & \text { OSCILATEK TXCO/112 } & 198319 & 01411 \text { WWV } \\ \text { RTD Ref.: } & \text { ROSEMONT-ADSR544 } & 150171 & 1285\end{array}$

Csi certhes the above instrument meets or exceeds publlshed specificafions and has been calibrate using standards and Instrumants whose accuracles are traceable to the Natlonal Inetitute of standards and Technology, an accepted value of a natural physical constant or a ratio callbration technique.

The massurement uncertalnty of the callbration process exceeds $4: 1$ accuracy ratlo.

The polieles and procadures at this callbration fuclity comply with $180-9004$.

Callbration date: Thursday, Fobruary 08, 2001

Callbration due: Frlday, February $\mathrm{OB}, 2002$ 


\section{CAMPBELL SCIENTIFIC, INC.} 815 W. 1800 N. Logan, Utth 84321-1784 (435) 753-2342 FAX (435) 750-8540 umw.campbellacl.com

\section{Certificate of Calibration}

\section{Customer:}

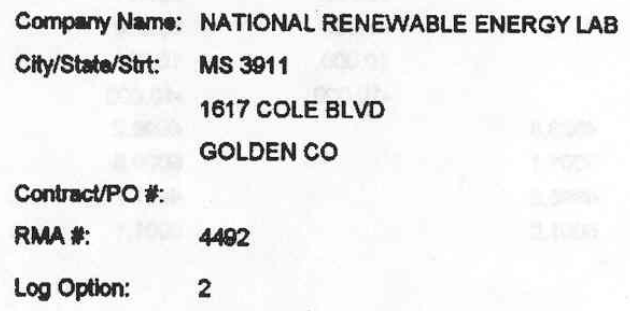

\section{Model: CR23X-4M}

Serial Number: 3099

Test Panel Loc. 2

CSI Callbration Number: 20781
PRC32A R8 TST10517C R17

PRC33A R 1

\section{Instrument Calibration Condition}

$\begin{array}{llll}\text { Recelved Dieposition: In Tolerance - } & \text { Out of Tolerance } \\ \text { Returned Dispoestion: In Tolerance } & & \end{array}$

\section{Recommended Calibration Schedule}

Based on past experlence and assumed normal usage, it is recommended that this inetrument be callbrated by due ciate stated below to insure sustained accuracy and rellable performance.

Calibration Date: $\quad$ 10/30/01 Manufacture's suggested recalibration date: $10 / 30 / 02$

\section{Report of Calibration Standards Used}

$\begin{array}{lccc}\text { Make/ Model } & \text { SN } & \text { Cal Dus Date } & \text { NIST reference } \\ \text { DP } 8200 & \text { A014824 } & 9 / 8 / 02 & \text { A014824 } \\ \text { CSI Oscillator } & 196319 & 5 / 18 / 02 & 196319\end{array}$

CSI certifles the above instrument mests or exceeds published specifications and hat been callbreted uaing stanchards and instruments whose accuracles are traceable to the Nationell instikte of Standarde and Technology, an accepted value of a natural physical constant or a ratio callbration bechnique. The collective measurement uncertainty of the callbration process exceeds a $4: 1$ ratio. The pollcies and procadures at this calibration faclity comply with isO-9001. The cellibration of thls inatrument was performed in accordance with CSF Quallty Aseurance program.

Quality Control Manager responalble for content of certificate: Clint Howell

\section{Remarks:}

Based on Report option, some fields are intentionally left blank.

This document shall not be reproduced except in full, without the written approval of Campbell Scientific, Inc.

Page 1 of 2 


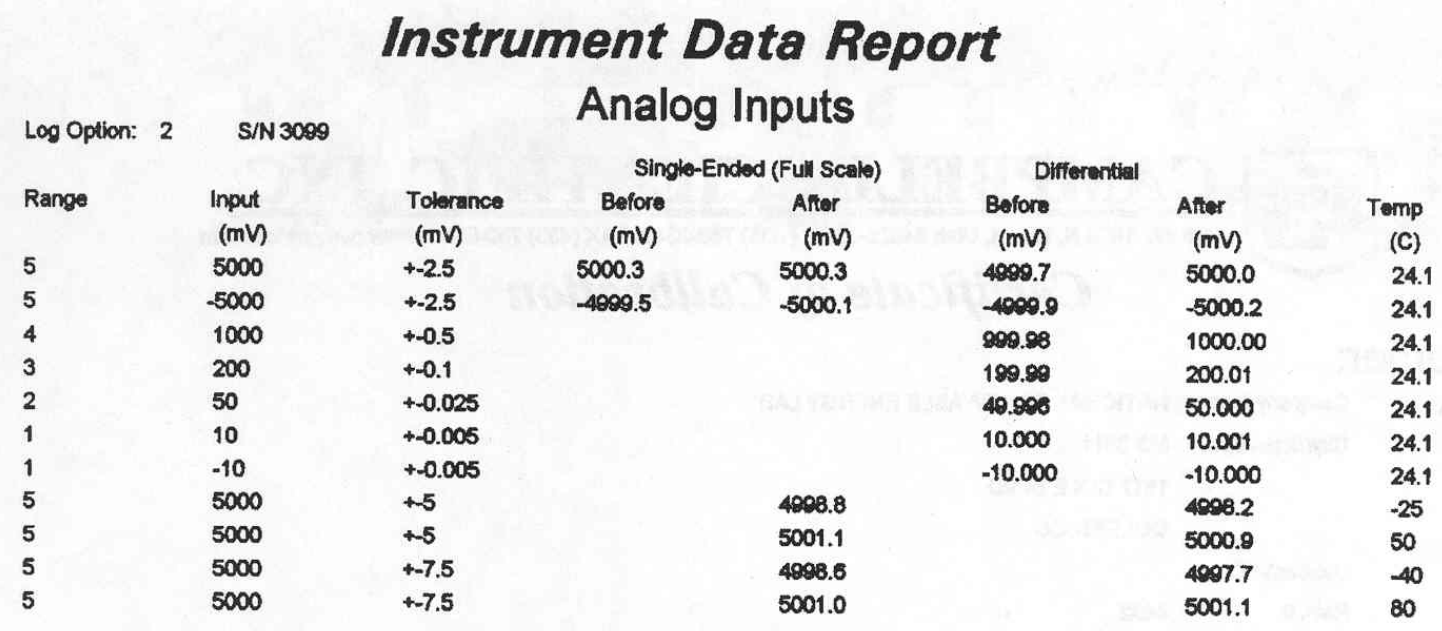

\section{Quiescent System Power}

Tolerance $\operatorname{Max}(\mathrm{ma})$

2.5

$\begin{array}{ll} & \\ \text { Tolerance } & \text { As Recelved } \\ \text { (min/month) } & \text { (min/month) } \\ +-1.33 \mathrm{~min} & -0.1 \\ +-1.33 \mathrm{~min} & \\ +-1.33 \mathrm{~min} & \\ +-2.66 \mathrm{~min} & \\ +-2.66 \mathrm{~min} & \end{array}$

$\begin{array}{ll}\text { As Retumed } & \text { Temp } \\ \text { (mA) } & \text { (C) } \\ 1.23 & 24.1\end{array}$

\section{Real-Time Clock}

$\begin{array}{ll}\text { As Roturned } & \text { Temp } \\ \text { (min/month) } & \text { (C) } \\ 0.0 & 24.1 \\ -0.2 & -25 \\ -0.4 & 50 \\ -0.5 & -40 \\ -0.6 & 80\end{array}$

Note: an "m+n with data indicates out of tolerance; an ${ }^{m+n}$ without data indicates operational failure.

Laboratory temperature and relative humidity at the time of calibration Temperature: $24.1 \mathrm{C}$ Relative Humidity: $19.2 \%$

\section{Functions tested per test document (see page 1):}

Analog:

Excitation Channela

CAO Channels

Analog Input ranges over temperature
Frequency:

Pulae Countors

Perlod Aversging

Calibration by: T. Arenderectronic Technician

T. KENDALL

Based on Report option, some flelds are intentionally left blank.

This document shall not be reproduced except in full, without the written approvel of Campbell Soientific, inc.

Page 2 of 2 
Appendix B - Safety and Function Test Checklist 


\section{System safety and function test procedures and checklist for the Whisper H40.}

The objective of the safety and function test is to verify that the turbine displays the behavior predicted in the design and that provisions relating to personnel safety are properly implemented.

However, this does not mean that the turbine is safe. If it is clear that a certain simulated fault would bring the turbine into an unstable situation, then this was not tested for. The outcome would be predictable. Only issues in which the system is supposed to respond or stay in a safe condition were evaluated. Below is a list of items that will be evaluated for the Whisper $\mathrm{H} 40$.

The signals needed for this test are: wind speed, DC voltage, AC power, rpm, and dump load status.

The italic text gives the test procedure.

The Arial text in the boxes is a reproduction of the notes taken during the measurements.

The tests were performed on June 25 and 26, 2001, by Mark Meadors and Jeroen van Dam.

Yaw orientation

Over the year, observations have been made during the acoustic noise tests. These were taken over a wide wind speed range [4-22 m/s (9-49 mph)] on different days. No abnormal behavior was noticed.

Power and rotor speed limitation

Rpm and power data have been measured in the duration test and can be used to check this part of the safety and function test.

Use the duration test data to determine plots of maximum rpm and maximum power as a function of wind speed.

Brake operation

Several braking operations have been done over the year. That experience will be used to check this part of the safety and function test.

Check logbook for brake entries and indication of wind speeds.

Grid outage

In case of a grid outage, the inverter will go down. The turbine should keep operating normally and the power should go to the batteries. When the batteries are full, the dump load should be switched in. If the grid is reconnected after this has happened, the dump load should switch off and the power should be delivered to the grid.

To test to see if the dump load can handle the maximum power, this test ideally should take place at wind speeds slightly above rated wind speed [10-15 m/s (22.4-33.6 mph)].

We will disconnect the grid on the grid side of the inverter. The expected behavior is that the turbine will operate normally, the inverter will go down, and the power will go to the batteries. After a while, the batteries will be full and power will go to the dump load.

After this, connect the grid again and the dump load should switch off and power should go to the grid.

Signals needed: wind, dump load sensing, and DC bus voltage.

Ideally high winds would be best to see if dump load can handle the maximum power. 
Observed behavior:

25 June 2001

A few minutes after the batteries were disconnected and the inverter shut down, the dump load started getting warm. Regulating LED switches on and off. Winds are in range of $6-11 \mathrm{~m} / \mathrm{s}(13.4-24.6 \mathrm{mph})$.

Battery disconnect

In case the batteries are disconnected, the turbine should continue normal operation. All the power should be delivered to the grid or dump load.

Open the switch to the batteries. Listen to the turbine noise for any significant changes in rpm. Observe the AC power and dump load status.

Signals needed: wind speed, AC power, dump load sense

Observed behavior:

25 June 2001

No change in rpm is audible, winds are around $6 \mathrm{~m} / \mathrm{s}$ (13.4 mph). At 12:25, the winds reach $10-11 \mathrm{~m} / \mathrm{s}(22.4-24.6 \mathrm{mph})$ and the turbine starts furling. Power goes to the grid.

Loss of load

In case any of the phases loses its connection to the EZwire, the turbine should speed up and the power should decrease. The more phases are disconnected, the higher the rpm and the lower the power (zero for three phases loose).

Pull one of the fuses at the tower bottom. Take measurements of DC power and rpm. Repeat the same measurement for two and three phases loose.

Observed behavior:

25 June 2001:

9:47-10:14 three phases loose.

10:17-10:46 two phases loose.

12:25-13:00 one phase loose.

Winds are between 2.5 and $12 \mathrm{~m} / \mathrm{s}$ (5.6 and $26.8 \mathrm{mph})$.

14:40 Winds reach $15 \mathrm{~m} / \mathrm{s}$ (33.6 mph). Pulled three phases loose. Turbine goes into occasional flutter. After the wind dies, the turbine gets stuck in furl twice $\left(20^{\circ}-30^{\circ}\right.$ furl angle).

15:13 Reconnected the phases.

Unauthorized changing of control settings.

A knob on the front panel of the EZwire is used to set charge voltage. A dangerous situation can be created for the batteries by turning this knob to a higher set point. 
Failure of furl system

The control of power and rpm is primary based on the furl mechanism. In case the furl mechanism fails, the rotor should speed up and eventually the rotor should come into flutter.

Block the furl mechanism. Tie a rope to the tail of the turbine such that the turbine can be yawed out of the wind in case of an unsafe situation. Start measurements of power and rpm. The wind speed should be reasonably low to start.

Observed behavior:

26 June 2001:

Blocked furl mechanism using hose clamps. Waited for winds all day. Removed hose clamps at the end of the day. No high winds have been recorded.

\section{Personnel safety}

Electrical safety

The turbine has been checked for electrical safety.

Write down notes on electrical safety: Are enclosures accessible? Can high voltages be touched? Are warning labels present, etc.?

All electrical wiring is behind doors that can only be opened with a screwdriver or something similar. Stickers warn for danger. Wires run through conduits.

Make remark about how lightning protection is configured on this turbine.

Turbine has no special lightning protection system.

The base of the tower is grounded. Measuring the resistance between tower and tower base leads to the conclusion that the tower itself is not grounded. Guy wires are not grounded.

Lowering and raising of the tower

The Whisper H40 as present at the NWTC is equipped with a tilt-down tower. The turbine has been tilted and raised a few times during the test period. According to the people performing this work, no difficulties were encountered and no hazardous situations have occurred. 


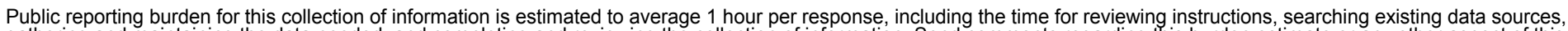

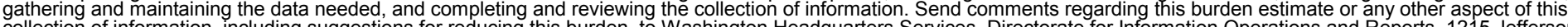
Davis Highway, Suite 1204, Arlington, VA 22202-4302, and to the Office of Management and Budget, Paperwork Reduction Project (0704-0188), Washington, DC 20503.
1. AGENCY USE ONLY (Leave blank)
2. REPORT DATE
3. REPORT TYPE AND DATES COVERED
June 2002
Technical Report

4. TITLE AND SUBTITLE

Wind Turbine Generator System Safety and Function Test Report for the Southwest

Windpower $\mathrm{H} 40$ Wind Turbine

6. $\operatorname{AUTHOR}(\mathrm{S})$

Jeroen van Dam, Hal Link, Mark Meadors, Jerry Bianchi

7. PERFORMING ORGANIZATION NAME(S) AND ADDRESS(ES)

National Renewable Energy Laboratory

8. PERFORMING ORGANIZATION REPORT NUMBER

1617 Cole Blvd.

Golden, CO 80401-3393

9. SPONSORING/MONITORING AGENCY NAME(S) AND ADDRESS(ES)

National Renewable Energy Laboratory

1617 Cole Blvd.

Golden, CO 80401-3393

5. FUNDING NUMBERS

TA: WER2 3215

11. SUPPLEMENTARY NOTES

12a. DISTRIBUTION/AVAILABILITY STATEMENT

National Technical Information Service

12b. DISTRIBUTION CODE

U.S. Department of Commerce

5285 Port Royal Road

Springfield, VA 22161

13. ABSTRACT (Maximum 200 words)

The objective of this test was to evaluate the safety and function characteristics of the Whisper H40 wind turbine. The general requirements of wind turbine safety and function tests are defined in the IEC standard WT01. The testing was conducted in accordance with the National Wind Technology Center (NWTC) Quality Assurance System, including the NWTC Certification Team Certification Quality Manual and the NWTC Certification Team General Quality Manual for the Testing of Wind Turbines, as well as subordinate documents. This safety and function test was performed as part of the U.S. Department of Energy's Field Verification Program for small wind turbines.

14. SUBJECT TERMS
Southwest Windpower H40 Wind Turbine; wind turbine; wind; test report; Field Verification Program

15. NUMBER OF PAGES

16. PRICE CODE

17. SECURITY CLASSIFICATION OF REPORT

Unclassified
18. SECURITY CLASSIFICATION OF THIS PAGE Unclassified
19. SECURITY CLASSIFICATION OF ABSTRACT Unclassified
20. LIMITATION OF ABSTRACT

UL 